\title{
Bible, Art, Gallery, edited by Martin O’Kane
}

Bible in the Modern World 2I | Sheffield: Phoenix Press, 20I I xix + I99 pages | ISBN: 978-I-906055-63-9 (hardcover) $£ 50.00$

This fascinating collection of essays contains papers presented at conferences held at the Barber Institute of Fine Arts, University of Birmingham, and at the

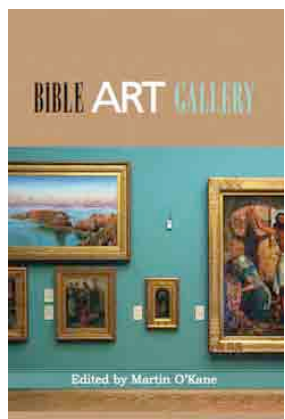
Manchester Art Gallery, highlighting some of the "hidden gems of biblical art" held in the collections of both galleries and assisted by funding from the British Academy. The papers presented at these conferences, drawn from the worlds of biblical studies, art history, philosophy, sociology and music, reflect the interdisciplinary goals of the project. These essays serve not only to showcase biblical paintings by lesser-known artists but also to illustrate the wide range of perspectives and insights conveyed by different academic disciplines.

Martin O'Kane, the editor, writes the introduction in which he describes the background to the British Academy Bible and Art project (2006-2007). All the essays of this collection are worthy of attention; here are highlights. Nicholas Davey's fine essay, "The Bible and Visual Exegesis", establishes a 
theoretical framework for the collection by exploring how viewing a biblical painting parallels the way we read a biblical text. Davey draws on Gadamer's Truth and Method, to distinguish between the way in which things are presented and things that are represented so as to be deciphered and interpreted. Gadamer resists decipherment: he says that what matters is not what words and images refer or defer to but what they say, that is, what their performance "brings forth" or makes happen. Meaning erupts beyond the intent of the artist, and beyond the denotative and connotative meanings of words. In the released energies of emergent meaning we find, I think, a primary locus for the experience of sacrality.

John Harvey's essay, "Framing the Word: Commentary, Context, and Composition," explores the role and function of the Bible in several Victorian paintings, especially in Hunt's iconic painting, The Light of the World. His acute observations about (dis)locations of paintings in galleries merit attention: "A gallery is to biblical artworks what a zoo is to wild animals: specimens are removed from their natural habitat, sometimes in order to preserve the species, and placed in enclosures, tamed and framed" (47).

In David Jasper's essay, "The Desert in Biblical Art," the focus on William Holman Hunt's The Scapegoat (I 854 ) conveys a particular relationship between biblical narratives and western depictions in art of the desert. MidVictorian artists at the time of the quest for the historical Jesus sought to render religious scenes from experience. Hunt's Scapegoat, for instance, renders details of the goat in the arid salt flats of the Dead Sea landscape in strange, authentic colors.

J. Cheryl Exum's essay, "Notorious Biblical Women in Manchester: Spencer Stanhope's Eve and Frederick Pickersgill's Delilah," reads two paintings of Eve and Delilah as visual exegesis that exposes particular interpretations, including male control of representation and even those that biblical writers suppress. She encourages viewers as consumers of visual images to interrogate coded messages about sexual identities and gender roles and consider "whether or not we wish to resist them" (96).

Siobhán Dowling-Long's essay, "Musical Instruments in Biblical Art: Evaristo Baschenis's Still Life with Musical Instruments," explores the significance of the five musical instruments and their importance in masterpieces of biblical art. Since violinmakers and musicians use physical terms to describe parts of instruments: body, back, ribs, neck, etc. The broken and decayed instruments symbolize the fall of humanity in Gen 3 and the fragmented human body in particular. 
John F. A. Sawyer, in his essay "Van Dyck's Ecce homo in the Barber Institute," explores the iconographic tradition behind this image of an isolated Jesus with particular emphasis on the intended reaction of the viewer.

Keith Tester, in the essay "Poussin, a Poem and a Sacred Story," argues, through the prism of Stoicism and by a particular reading of Tancred's hands, that Poussin's Tancred and Erminia should be understood as a interpretation of the biblical narrative of the encounter between Mary Magdalene and Jesus in John 20.

Martin O'Kane's concluding essay "Who is Esau (Genesis 27:32)? Matthias Stom's Isaac Blessing Jacob in the Barber Institute of Fine Arts," reflects on the prominent location of the Stom painting in the gallery in order to refocus on Esau and present a history of Esau (re)presentations.

Individually and cumulatively the essays convey remarkable insights. They also model integrative work on the intersections of art and biblical interpretation that could be replicated in other contexts.

Deirdre Good

General Theological Seminary

New York City 